\title{
AsChip
}

\section{A High-Throughput qPCR Chip for Comprehensive Profiling of Genes Linked to Microbial Cycling of Arsenic}

Zhao, Yi; Su, Jian Qiang; Ye, Jun; Rensing, Christopher; Tardif, Stacie; Zhu, Yong Guan; Brandt, Kristian Koefoed

\section{Published in:}

Environmental Science and Technology

DOI:

10.1021/acs.est.8b03798

Publication date:

2019

\section{Document version}

Publisher's PDF, also known as Version of record

Document license:

Other

Citation for published version (APA):

Zhao, Y., Su, J. Q., Ye, J., Rensing, C., Tardif, S., Zhu, Y. G., \& Brandt, K. K. (2019). AsChip: A HighThroughput qPCR Chip for Comprehensive Profiling of Genes Linked to Microbial Cycling of Arsenic. Environmental Science and Technology, 53(2), 798-807. https://doi.org/10.1021/acs.est.8b03798 


\title{
AsChip: A High-Throughput qPCR Chip for Comprehensive Profiling of Genes Linked to Microbial Cycling of Arsenic
}

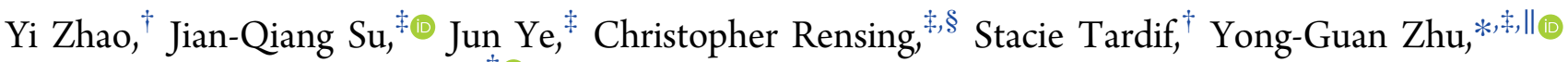 \\ and Kristian Koefoed Brandt ${ }^{*}+\bullet$
}

\begin{abstract}
${ }^{\dagger}$ Section for Microbial Ecology and Biotechnology, Department of Plant and Environmental Sciences, University of Copenhagen, Thorvaldsenvej 40, DK-1871 Frederiksberg C, Denmark

${ }^{\ddagger}$ Key Laboratory of Urban Environment and Health, Institute of Urban Environment, Chinese Academy of Science, 1799 Jimei Road, Xiamen 361021, China

${ }^{\S}$ Institute of Environmental Microbiology, College of Resources and Environment, Fujian Agriculture and Forestry University, Fuzhou 350002, Fujian China

"State Key Laboratory of Urban and Regional Ecology, Research Center for Eco-Environmental Sciences, Chinese Academy of Sciences, Beijing 100085, China
\end{abstract}

\section{Supporting Information}

ABSTRACT: Arsenic (As) is a ubiquitous toxic element adversely affecting human health. Microbe-mediated cycling of As is largely mediated by detoxification and energy metabolism in microorganisms. We here report the development of a novel high-throughput qPCR (HT-qPCR) chip (AsChip) for comprehensive profiling of genes involved in microbial As cycling (here collectively termed "As genes"). AsChip contained 81 primer sets targeting 19 As genes and the $16 \mathrm{~S}$ rRNA gene as a reference gene. Gene amplicon sequencing showed high identity $(>96 \%)$ of newly designed primers corresponding to their targets. AsChip displayed high sensitivity (plasmid template serial dilution test; $r=-0.99$ ), with more than $96 \%$ of all PCR assays yielding true positive signals. $R^{2}$ coefficients for standard curves and PCR amplification efficiencies averaged 0.98 and 0.99 , respectively. A high correlation between $\mathrm{C}_{\mathrm{T}}$ values obtained by AsChip and conventional qPCR was obtained $(r=0.962, P<0.001)$. Finally, we successfully applied AsChip on soil samples from a chromium-copper-arsenic-contaminated field site and identified diverse As genes with total abundance average of 0.4 As gene copies per $16 \mathrm{~S}$ rRNA. Our results indicate that AsChip constitutes a robust tool for comprehensive quantitative profiling of As genes in environmental samples.

\section{INTRODUCTION}

Arsenic (As) is a ubiquitous toxic element impacting human health. ${ }^{1}$ It is present in the atmosphere, hydrosphere, pedosphere, and biosphere with both natural and anthropogenic origins. ${ }^{2-5}$ Arsenic in the environment primarily poses health risks to humans via water ${ }^{6}$ or food $^{7-9}$ and has been linked to various cancers, ${ }^{10}$ cardiovascular disease, ${ }^{11}$ diabetes, ${ }^{12}$ and skin lesions. ${ }^{13}$ The toxicity, mobility, and environmental fate of As are to a large extent determined by its chemical speciation. ${ }^{14}$ For example, inorganic As species prevalent in drinking water are much more toxic than arsenobetaine, which is the primary source of As in fish meat. ${ }^{15}$ Hence, the following toxicity order of arsenicals have been reported for humans: inorganic As(III) > dimethylarsenite [DMAs(III)] > dimethylarsenate $[\mathrm{DMAs}(\mathrm{V})]>$ monomethylarsenate $[\operatorname{MMAs}(\mathrm{V})]>$ inorganic $\mathrm{As}(\mathrm{V}){ }^{16}$

Environmental As speciation is profoundly impacted by microbial activity. Dissimilatory As oxyanion oxidation and reduction constitute ancient types of bacterial energy

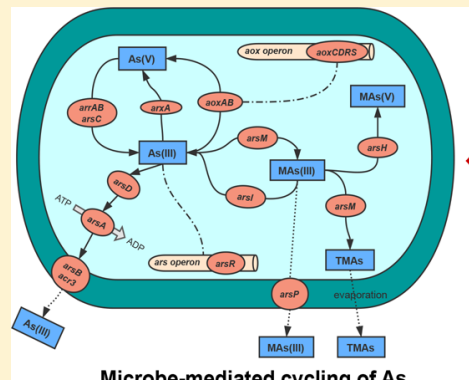

Microbe-mediated cycling of As

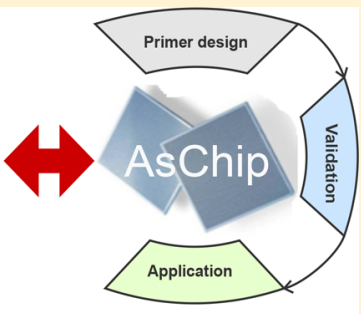

Development of AsChip 
a

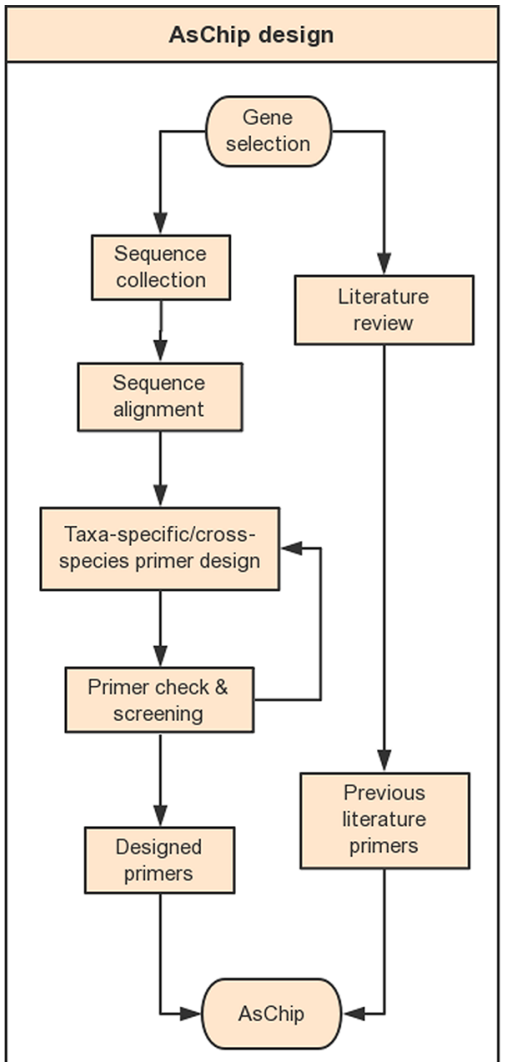

b

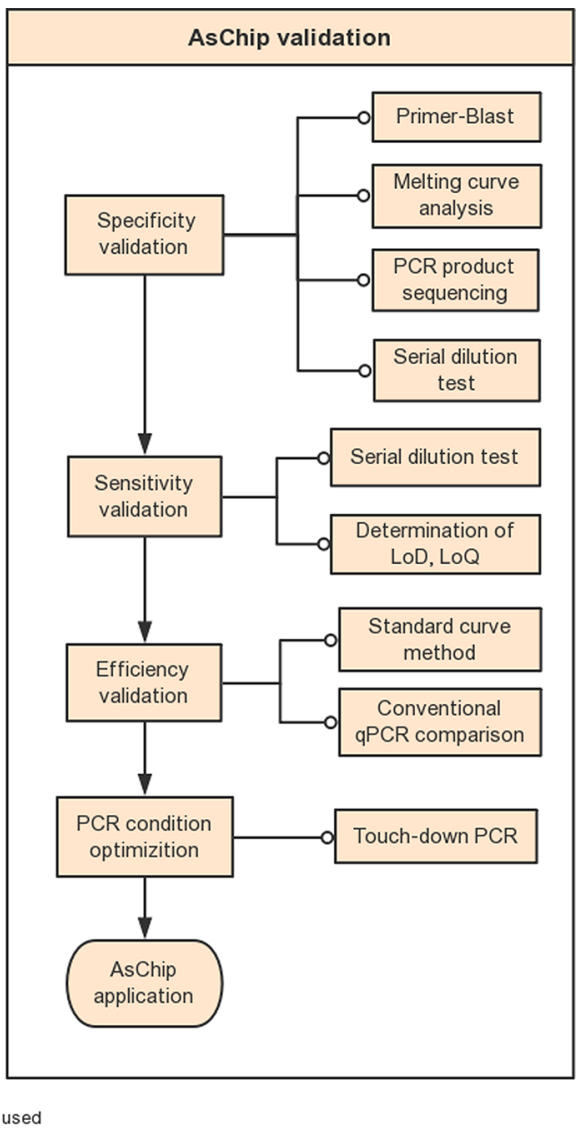

Figure 1. Flowchart of major steps for development of AsChip, including (a) design and (b) validation.

generating energy from inorganic As biotransformations, the latter group includes prokaryotes carrying out a wide range of contrasting As biotransformation processes. A major subgroup includes heterotrophic arsenite oxidizers (HAO) transforming toxic arsenite into the less toxic arsenate. Conversely, other bacteria reduce arsenate into arsenite and couple it to arsenite efflux to confer As resistance. Finally, a range of microorganisms transform organoarsenicals, of which many are volatile and highly mobile. Despite their immense biogeochemical significance, only little is known about the physiological purposes of these As biotransformations. ${ }^{2}$

A large number of genes (here collectively conferred to as "As genes") are involved in microbe-mediated cycling of As and constitute promising functional gene markers for studies of As biotransformation processes and the various functional groups of prokaryotes that carry out these processes. ${ }^{18}$ For example, inorganic arsenate can be reduced to arsenite by arsenate reductase encoded by $\operatorname{ars} C$ (resistance) or $\operatorname{arr} A B$ (anaerobic As respiration), whereas the toxic As(III)/MAs(III) can be pumped out of bacterial cells by arsenic transporters encoded by $\operatorname{ars} B$, ars $P$, or $a c r 3$ (resistance). Arsenite or organoarsenical oxidases encoded by arxA (dissimilatory arsenite oxidation), aio $A B$ (resistance), or $\operatorname{arsH}$ (resistance) may further transform $\mathrm{As}(\mathrm{III}) / \mathrm{MAs}(\mathrm{III})$ to the less toxic As $(\mathrm{V}) / \mathrm{MAs}(\mathrm{V})$. As methylation is encoded by arsM (resistance) and results in the loss of As by volatilization or products such as mono-, di- or trimethylarsines, ${ }^{21}$ demethylation of trivalent organoarsenicals (MAs[III] and roxarsone) is catalyzed by $\mathrm{C}$.As lyase encoded by arsI as part of a resistance pathway. $^{22-24}$
Our knowledge about As biotransformation processes and the underlying microbial ecology is incomplete in part due to the lack of comprehensive, targeted methods to comprehensively study As-transforming microorganisms. With the development of next-generation sequencing (NGS) technologies and their decreasing costs, metagenomic and metatranscriptomic studies of As biotransformation are beginning to emerge. ${ }^{25-27}$ However, these approaches only provide relative abundances of targeted genes and their transcripts and should therefore ideally be complemented by their high throughput quantification. Quantitative polymerase chain reaction (qPCR) represents one of the most widely applied techniques for quantifying functional genes and has already been used in several environmental studies of As biogeochemistry. ${ }^{21,28-37}$ This technique generally provides more sensitive detection of genes in environmental samples as compared to hybridization microarray technology (e.g., the GeoChip). ${ }^{38,39}$ However, conventional single-gene qPCR gets laborious and impractical when many genes have to be quantified at the same time as would be necessary for comprehensive monitoring of all As genes in environmental samples. ${ }^{35,37}$ Hence, we aimed to develop and validate a novel high-throughput qPCR (HTqPCR)-based chip for sensitive, rapid, and cost-efficient quantification of known prokaryotic As genes. The developed HT-qPCR chip (AsChip) targets 19 microbe-mediated As cycling genes and the bacterial $16 \mathrm{~S}$ rRNA gene as a reference gene. AsChip employs a total of 81 cross-species primer sets covering hundreds of species with 70 primer sets being newly developed and validated as part of the present study. 
Table 1. Summary of Genes Targeted by AsChip, Microorganisms Hosting Genes, and Numbers of AsChip qPCR Primers Used To Detect Genes ${ }^{a}$

\begin{tabular}{|c|c|c|c|c|c|c|c|}
\hline \multirow[b]{2}{*}{ Gene type } & \multirow[b]{2}{*}{ Functional process } & \multirow[b]{2}{*}{ Encoded proteins } & \multirow[b]{2}{*}{ Functionality } & \multirow[b]{2}{*}{ Microbes } & \multicolumn{2}{|c|}{ No. of primer pairs } & \multirow[b]{2}{*}{ ref } \\
\hline & & & & & Designed & Published & \\
\hline aoxA/aioB & As(III) oxidation & $\begin{array}{l}\text { As(III) oxidase small } \\
\text { subunit }\end{array}$ & As(III) oxidation & $\mathrm{HAO}$ & 3 & 1 & 73 \\
\hline aoxB/aioA & & $\begin{array}{l}\text { As(III) oxidase large } \\
\text { subunit }\end{array}$ & As(III) oxidation & $\mathrm{HAO}$ & 3 & 1 & 73 \\
\hline aoxR/aioR & & response regulator & regulation of aox/aio operon expression & $\mathrm{HAO}$ & 3 & 1 & 73 \\
\hline aoxs/aios & & sensor histidine kinase & $\begin{array}{l}\text { part of two-component signal transduction } \\
\text { system }\end{array}$ & $\mathrm{HAO}$ & 3 & 1 & 73 \\
\hline ars $H$ & & organoarsenical oxidase & trivalent organoarsenicals oxidation & ARM & 3 & 0 & 23 \\
\hline aoxC/aioC & & cytochrome c & encoding c-type cytochrome in aox/aio operon & $\mathrm{HAO}$ & 1 & 1 & 74 \\
\hline aoxD/aioD & & $\begin{array}{l}\text { chlE - molybdoptein } \\
\text { biosynthesis }\end{array}$ & $\begin{array}{l}\text { encoding an enzyme invovled in molybdoptein } \\
\text { biosynthesis in aox/aio operon }\end{array}$ & $\mathrm{HAO}$ & 1 & 1 & 74 \\
\hline $\operatorname{ar} x A$ & & As(III) oxidase & As(III) oxidation & $\mathrm{CAO}$ & 1 & 0 & 75 \\
\hline $\operatorname{arr} A$ & As $(\mathrm{V})$ reduction & $\begin{array}{l}\operatorname{As}(\mathrm{V}) \text { respiratory } \\
\text { reductase large subunit }\end{array}$ & As $(V)$ reduction & DARP & 1 & 1 & 36,76 \\
\hline $\operatorname{arrB}$ & & $\begin{array}{l}\mathrm{As}(\mathrm{V}) \text { respiratory } \\
\text { reductase small subunit }\end{array}$ & $\mathrm{As}(\mathrm{V})$ reduction & DARP & 1 & 0 & 36,77 \\
\hline $\operatorname{ars} C$ & & As $(V)$ reductase & As $(V)$ reduction & ARM & 13 & 2 & 77 \\
\hline $\operatorname{ars} R$ & & transcriptional repressor & regulation of ars operon expression & ARM & 8 & 0 & 77 \\
\hline $\operatorname{ars} I$ & $\begin{array}{l}\text { Arsenic methylation } \\
\text { and demethylation }\end{array}$ & C-As bond lyase & $\begin{array}{l}\text { demethylation of trivalent organoarsenicals to } \\
\text { less toxic As(III) }\end{array}$ & AMM & 4 & 0 & 23 \\
\hline $\operatorname{ars} M$ & & $\begin{array}{l}\text { As(III) } \\
\text { methyltransferases }\end{array}$ & arsenic methylation & AMM & 5 & 0 & 23 \\
\hline $\operatorname{ars} A$ & Arsenic transport & As(III)-activated ATPase & catalysis of oxyanion-translocating ATPase & ARM & 7 & 0 & 78 \\
\hline $\operatorname{ars} B$ & & $\begin{array}{l}\text { As(III) efflux pump } \\
\text { protein }\end{array}$ & extrusion of As(III) from the cell & ARM & 6 & 0 & 79 \\
\hline $\operatorname{ars} D$ & & $\begin{array}{l}\text { arsenical } \\
\text { metallochaperone }\end{array}$ & transfer of trivalent metalloids to ars $A$ & ARM & 3 & 0 & 78 \\
\hline $\operatorname{ars} P$ & & $\begin{array}{l}\text { trivalent organoarsenicals } \\
\text { permease }\end{array}$ & $\begin{array}{l}\text { extrusion of trivalent organoarsenicals from the } \\
\text { cell }\end{array}$ & ARM & 2 & 0 & 80 \\
\hline acr3 & & $\begin{array}{l}\text { As }(\mathrm{III}) \text { efflux pump } \\
\text { protein }\end{array}$ & extrusion of As(III) from the cell & ARM & 2 & 1 & 81,82 \\
\hline $\begin{array}{l}\text { Total } 19 \\
\text { genes }\end{array}$ & & & & & 70 & 10 & \\
\hline
\end{tabular}

${ }^{a}$ Detailed information on all primer sets is shown in Table S1. Abbreviations used: Heterotrophic arsenite oxidizers, HAO; Arsenic resistant microbes, ARM; Chemoautotrophic arsenite oxidizers, CAO; Dissimilatory arsenate-reducing prokaryotes, DARP; Arsenic methylating microbes, AMM.

\section{MATERIALS AND METHODS}

Design of AsChip. Major steps for AsChip design are shown in Figure 1a. A total of 19 targeted genes of relevance for microbial cycling of As were selected (Table 1). Collectively, these targeted genes encode As(III) oxidation, $\mathrm{As}(\mathrm{V})$ reduction, As methylation, As demethylation, and As transport (efflux). Ten validated primer pairs were selected from previously published studies, whereas a total of 70 novel primer pairs were designed as part of this study (Table 1; Table S1). Primer design was performed based on target gene sequences retrieved from the National Center for Biotechnology Information (NCBI) GenBank database. Gene sequences were obtained from both bacteria and archaea and were further collected and aligned using MEGA 7.0 with ClustalW. Sequences were clustered into different groups using a neighbor-joining phylogeny tree based on alignment results. SYBR Green Design of AlleleID 6.0 was used to design taxaspecific/cross-species primers for top clustered groups of each gene. The cross-species primers were designed based on conserved regions found in clustered groups. The quality of designed primers and expected priming efficiency were further checked by AlleleID 6.0 with the following criteria: primer length of 18-24 bases, amplicon length of 50-200 bases, GC content of $40 \%-60 \%$, expected melting temperature $\left(T_{\mathrm{m}}\right)$ of product at $48-62{ }^{\circ} \mathrm{C}$, hairpin $\Delta G \geq-3 \mathrm{kcal} / \mathrm{mol}$, self-dimer $\Delta G \geq-6 \mathrm{kcal} / \mathrm{mol}$, cross-dimer $\Delta G \geq-6 \mathrm{kcal} / \mathrm{mol}$, and GC clamp $\leq 3$. $^{40,41}$ Only primers meeting the above quality criteria were used for further validation and application. The bacterial 16S rRNA gene was included in the construction of AsChip as a reference gene using the universal primers $1108 \mathrm{~F} / 1132 \mathrm{R}^{42}$ Detailed information on the 81 primer sets is shown in Table S1.

Validation of AsChip. Major steps of AsChip validation are shown in Figure 1b. The specificity of AsChip was validated computationally and experimentally. Computationally, Primer-BLAST ${ }^{43}$ was used to check newly designed primers for specificity against the NCBI nucleotide collection (nr) database with bacteria (taxid:2) and archaea(taxid:2157) as target organisms with a max target size of 1000 bases. All newly designed primers were also tested experimentally by PCR using DNA extracted from contrasting environmental samples as templates. DNA were extracted from samples 
collected from a chromium-copper-arsenic contaminated soil $^{44}$ estuaries (sediment), ${ }^{42}$ and urban sewage (water). ${ }^{45}$ Water samples were filtered through a $0.22 \mu \mathrm{m}$ cellulose nitrate membrane filter to collect bacterial pellets prior to DNA extraction. Detailed protocols for DNA extraction of sediment and water samples were described previously. ${ }^{42,45}$ The detailed protocol for DNA extraction from soil samples is described in the section entitled Application of AsChip on Environmental Samples. The purity of DNA was checked (ND-1000, Nanodrop, USA), and DNA was diluted to the same concentration with sterile water for later use. A total of 53 different PCR amplicons were detected and checked via agarose gel electrophoresis and Sanger sequencing ${ }^{46}$ (company Bioray, Xiamen, China). Amplicon sequences were assembled and aligned with target sequences using the software DNAMAN v9.0. Furthermore, AsChip primer specificities were routinely monitored by analysis of melting curves in all downstream AsChip HT-qPCR experiments using the Wafergen SmartChip Real-time PCR system. For regular PCR, each $50 \mu \mathrm{L}$ PCR reaction contained $25 \mu \mathrm{L}$ TaKaRa PremixTaq (ExTaq), $1 \mu \mathrm{L}$ of each primer, $22 \mu \mathrm{L}$ PCR grade water, and $1 \mu \mathrm{L}$ DNA template. The thermal cycle consisted of an initial polymerase activation at $95{ }^{\circ} \mathrm{C}$ for $10 \mathrm{~min}$ and 40 cycles of denaturation $\left(95{ }^{\circ} \mathrm{C}, 30 \mathrm{~s}\right)$, annealing $\left(58^{\circ} \mathrm{C}, 30 \mathrm{~s}\right)$, and extension $\left(72{ }^{\circ} \mathrm{C}, 120 \mathrm{~s}\right)$.

The serial dilution test and standard curve analysis were conducted to validate specificity, sensitivity, and efficiency using plasmids as positive controls. Gene fragments targeted by all the 70 newly designed primers were synthesized and cloned into plasmids cloning vector pUC57-Ampicillin (GENEWIZ, Inc.). The size and sequence of all the artificial target fragments $\left(5^{\prime} \rightarrow 3^{\prime}\right)$ are listed in Table S1. To develop standard curves for further evaluation, these plasmid DNA containing target gene fragments were mixed (40 ng each) into one mixed positive control. Ten-fold dilution series covering from 1 to $10^{11}$ plasmid copies per reaction were prepared to generate standard curves for AsChip HT-qPCR analyses. Standard curve fitting was performed with linear regression analysis using OriginPro 9.1. The optimal cutoff point was determined as the maximum qPCR cycle of quantitative detection in serial dilution with true-positive and true-negative signals. The limit of detection (LoD) was determined as the lowest amount of target that could be detected. The limit of quantification was determined as the lowest amount of target that could be quantified with true-positive/negative signal, corresponding to the optimal cutoff point in the standard curve. The qPCR primer amplification efficiency was calculated using standard curve with the equation: $\mathrm{Eff}=10^{(-1 / \text { slope })}-1$, where slope corresponds to the slope of the standard curve. AsChip HTqPCR data generated for all 70 novel primer pairs was further validated by conventional qPCR conducted on the LightCycler480 Real-Time PCR System using the same PCR conditions and the same environmental samples.

The qPCR conditions for the AsChip HT-qPCR system were optimized using touch-down PCR (TD-PCR) with five randomly selected designed primer pairs. ${ }^{47}$ TD-PCR products were checked by agarose gel electrophoresis. An optimal annealing temperature of $58{ }^{\circ} \mathrm{C}$ was determined by TD-PCR with the expected optimum annealing temperature $\left(\mathrm{T}_{\mathrm{a}} \mathrm{Opt}\right)$ and melting temperature $\left(\mathrm{T}_{\mathrm{m}}\right)$ of the product generated by AlleleID also considered. The thermal cycle consisted of initial enzyme activation $10 \mathrm{~min}$ at $95^{\circ} \mathrm{C}$, followed by 40 cycles of denaturation at $95{ }^{\circ} \mathrm{C}$ for 30 s, annealing at 48 to $60{ }^{\circ} \mathrm{C}$ with temperature increments of $0.3{ }^{\circ} \mathrm{C}$ per cycle for 30 s, and extension at $72{ }^{\circ} \mathrm{C}$ for 120 s. Apart from this, TD-PCR reaction conditions were the same as described previously for regular PCR. Template DNA was extracted from the CCA contaminated soil site in Fredensborg as described below. All regular PCR/TD-PCR were performed on Bioer LifePro Thermal Cycler (Bioer Technology Co., Ltd.) with technical triplicates and included negative controls.

Application of AsChip on Environmental Samples. AsChip was tested with DNA extracted from three topsoil samples from an abandoned Danish wood impregnation site contaminated with different levels of chromium, copper, and arsenic. ${ }^{44,48}$ Approximately $500 \mathrm{~g}$ of three topsoil samples were collected in sterile plastic bags. After homogenization, approximately $5 \mathrm{~g}$ of soil was transferred to sterile $15 \mathrm{~mL}$ tubes, transported to the laboratory $(<1 \mathrm{~h}$ of transport) in an ice-cooled box, and subsequently stored at $-20{ }^{\circ} \mathrm{C}$ until DNA extraction. A MoBio PowerSoil DNA Isolation Kit was used for DNA extraction. DNA quality was checked via ultraviolet absorbance (ND-1000 Spectrophotometer, NanoDrop, Thermo Fisher Scientific). DNA was diluted to $30 \mathrm{ng} \mu \mathrm{L}^{-1}$ with sterile PCR grade water and stored at $-20{ }^{\circ} \mathrm{C}$. Soil DNA was subsequently analyzed by HT-qPCR AsChip on Wafergen SmartChip Real-time PCR system with the format of 81 assay $\mathrm{X} 54$ sample in $50 \mathrm{~nL}$ reaction system. The thermal cycle consisted of initial enzyme activation for $10 \mathrm{~min}$ at $95{ }^{\circ} \mathrm{C}$, followed by 40 cycles of denaturation at $95{ }^{\circ} \mathrm{C}$ for $30 \mathrm{~s}$, and annealing/extension at an optimized temperature of $58{ }^{\circ} \mathrm{C}$ for 30 s. Only genes with positive amplification of all technical triplicates were considered positive for gene detection and subsequently used for data analysis. All HT-qPCRs performed in this study was performed in technical triplicates and included negative and positive controls.

Statistical Analysis. AsChip data were analyzed to quantify genes involved in microbial As cycling. Absolute abundance (copy numbers per gram of soil) of $16 \mathrm{~S}$ rRNA genes was calculated with the standard curve method of quantification with a $\mathrm{C}_{\mathrm{T}}$ value of 31 as the detection limit where $C_{T}$ equals the threshold cycle. ${ }^{49}$ Absolute As gene copy numbers were calculated using the following formula: absolute As gene copy number $=$ (relative As gene copy number/ relative $16 \mathrm{~S}$ rRNA gene copy number) $\times$ absolute $16 \mathrm{~S}$ rRNA gene copy number, where relative gene copy number = $10^{\left(31-\mathrm{C}_{\mathrm{T}}\right) /(10 / 3)} .^{50}$ Normalized As gene abundances were calculated as As gene copy numbers per 16S rRNA gene. The flowchart was generated using ProcessOn (Damai Co. Ltd., Beijing, China). The bar chart, box chart, and scatter diagram were plotted by OriginPro 9.1. Linear regression analyses were performed on OriginPro 9.1, and the liner fit, confidence, and prediction bands were generated automatically. Heatmap analysis and cluster analysis were performed using HemI. ${ }^{51}$

\section{RESULTS AND DISCUSSION}

Coverage and Specificity of AsChip. The developed AsChip targets almost all known prokaryotic As genes, ${ }^{2,18}$ (Table 1 and Table S1). Validations of AsChip primer specificities were performed both in silico using PrimerBLAST and experimentally. Primer-BLAST identified a total of approximately 6500 target sequences with the 70 newly designed primers. Almost all gene targets (98.9\%) were derived from diverse bacterial phyla, whereas the remaining fraction originated from archaea (Euryarchaeota). Bacterial phyla 
covered by AsChip primers included Proteobacteria, Firmicutes, Actinobacteria, Bacteriodetes, Cyanobacteria, Verrucomicrobia, and Fusobacteria. We randomly selected five As genes in order to calculate the fraction of known annotated As gene sequences (Genbank) that could be amplified by the designed AsChip primers. The fraction of sequences targeted by the selected As genes were as follows: aoxA (67\%; 4 out of $6)$, $\operatorname{ars} \mathrm{C}(80 \% ; 228$ out of 286$)$, arsH ( $60 \% ; 116$ out of 192$)$, $\operatorname{arsM}(62 \% ; 46$ out 74$)$, and $\operatorname{arsR}(64 \% ; 492$ out of 772$)$, demonstrating adequate coverage of AsChip. Primer-BLAST matches of $100 \%$ between primers and their target sequences were obtained for all designed primers using the NCBI nr database (organisms limited to Bacteria and Archaea). Primer specificities were further tested experimentally by the melting curve analysis on HT-qPCR reactions with all 70 newly designed primers targeting As genes. All melting curves of qPCR generated with AsChip showed the presence of a single peak, suggesting the success of designed primers for their specificity. The specificity was double checked and further confirmed by Sanger sequencing of all amplified PCR products $(n=53)$ obtained with newly designed primer pairs. Agarose gel electrophoresis of amplified PCR products in all cases showed a single band of the expected size, and DNA sequencing further revealed that the obtained amplicons corresponded well to their respective targets (Figure 2).

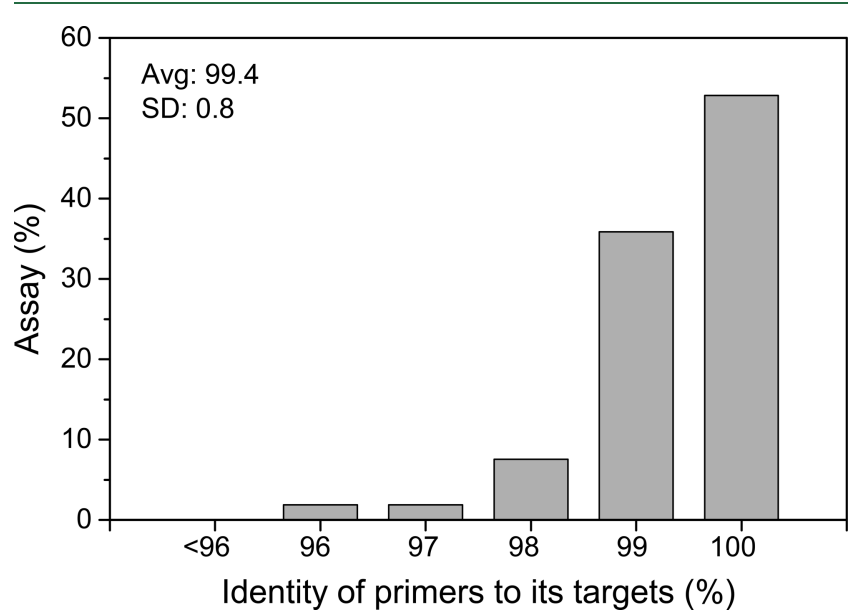

Figure 2. Specificity of newly designed AsChip primers was evaluated by sequencing of their corresponding PCR amplicons $(n=53)$. The figure depicts the distribution of PCR assays (\%) against the amplicon sequence similarity (\%) to their respective targets used for primer design.

Hence, amplicon sequences in all cases showed high similarity to their targets (>96\%) with $89 \%$ of the primers resulting in amplicon sequences with $\geq 99 \%$ similarity to their respective targets. The serial dilution test displayed true-positive amplifications of only targeted sequences, whereas no amplicons could be detected for negative controls (i.e., no template) with the absence of any primer secondary structures. Collectively, our results thus demonstrated a high and satisfactory specificity of AsChip suggesting a low risk for false positive detection of As genes.

Sensitivity and Efficiency of HT-qPCR AsChip and Comparison with Conventional qPCR. The performance of AsChip was assessed by estimating its sensitivity using standard curves generated by serial dilution test with mixed plasmids serving as positive controls (Figure 3; Figure S1).

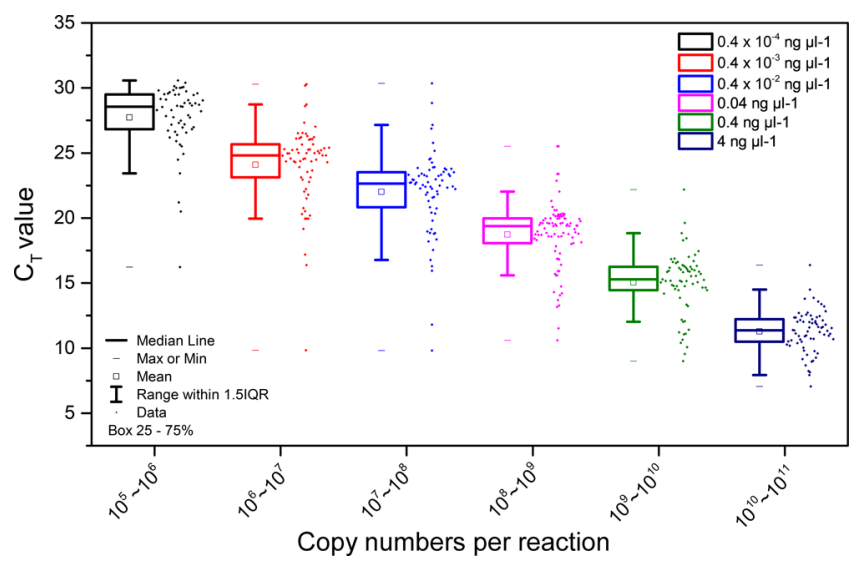

Figure 3. AsChip sensitivity (serial dilution test) with 70 newly designed primers as evaluated by 10 -fold serial dilution of mixed positive plasmid controls. Dots on the right side of boxes represent data obtained for individual primer pairs. Plasmid DNA concentrations are indicated in the figure (upper right). IQR, interquartile range.

The results demonstrated a high sensitivity of AsChip. $\mathrm{C}_{\mathrm{T}}$ values corresponding to positive plasmid template concentrations of $4 \times 10^{-5}$ to $4 \mathrm{ng} \mu \mathrm{L}^{-1}$ ranged from 7 to 31 . Within this template concentration range, more than $96 \%$ of all PCR assays yielded true positive signals, whereas standard curve Pearson correlation coefficients and $R^{2}\left(4 \times 10^{-5}\right.$ to $4 \mathrm{ng} \mu \mathrm{L}^{-1}$ range) averaged -0.99 and 0.98 , respectively (Table S2). For the more efficient application of AsChip, the optimal cutoff point, the LoD, and the limit of quantification (LoQ) were determined by standard curve analysis of serial dilution (Table S3). The optimal cutoff points for $C_{T}$ values of the 70 newly designed primers ranged from 26 to 31 with an average of 30 . The LoD varied from 7 to 262 target copies with 61 as the average, while LoQ varied from 11 to 132,667 target copies with an average of 10,319.

HT-qPCR AsChip performance for all 70 newly designed primers was further validated by calculating qPCR efficiency indices and $R^{2}$ based on standard curves (Figure 4; Table S2). PCR efficiency indices averaged 0.99 with a standard deviation

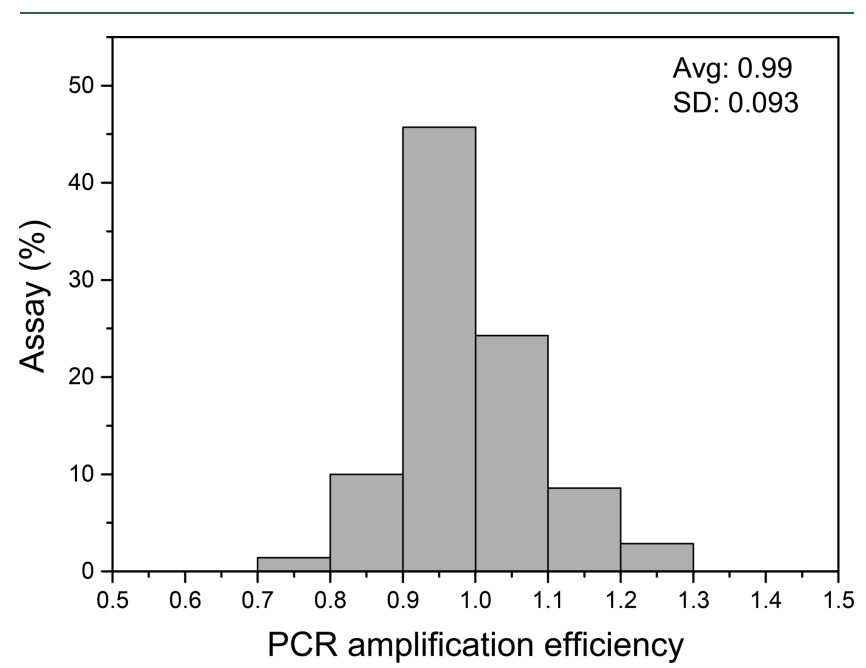

Figure 4. Distribution of AsChip HT-qPCR amplification efficiency with 70 newly designed primers. Standard curves and their parameters are shown in Figure S1 and Table S2. 
of 0.09 and ranged between 0.77 and 1.26 with the vast majority in the range of $0.8-1.2$ (Figure 4 ). $R^{2}$ coefficients for standard curves averaged $0.98 \pm 0.01$ ( \pm standard deviation). A potential deviation on normalized abundances (i.e., As gene copy number per $16 \mathrm{~S}$ rRNA gene) might occur when applying comparative $\mathrm{C}_{\mathrm{T}}$ since it was based on the assumption of the same amplification efficiency of all amplicons. However, for future AsChip application, this can be overcome with absolute quantification of each target with the standard curve method, by increasing primer concentration, or by optimizing the primer to specific $T_{m}$.

The high sensitivity and robust performance of AsChip were further confirmed by comparing $\mathrm{C}_{\mathrm{T}}$ values obtained by nanoliter-scale AsChip analysis with traditional microliterscale qPCR (Figure 5). $\mathrm{C}_{\mathrm{T}}$ values obtained by the two qPCR

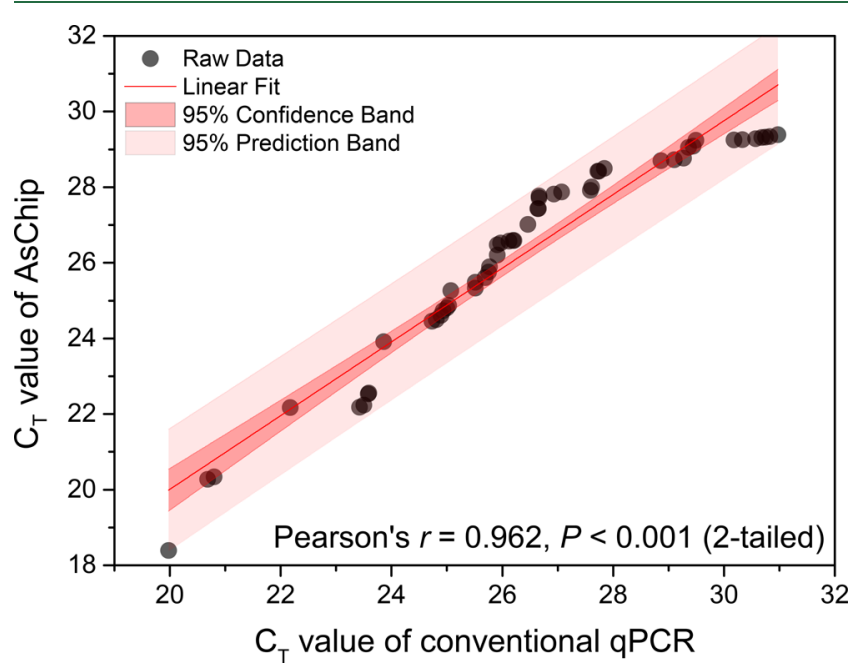

Figure 5. AsChip performance as evaluated against conventional single-gene qPCR by comparison of $\mathrm{C}_{\mathrm{T}}$ (cycle threshold) values $(n=$ 52). Linear regression analysis revealed a linear correlation (Pearson's $r=0.962, P<0.001)$ between the $\mathrm{C}_{\mathrm{T}}$ values obtained from the two qPCR platforms (conventional single-gene qPCR and AsChip). platforms showed a significant positive correlation (Pearson's $r$ $=0.962, P<0.01)$, indicating a high degree of reliability and reproducibility of AsChip (Figure 5). Hence, similar PCR efficiencies and detection limits were obtained by the two qPCR platforms in accordance with previous reports from the development of other HT-qPCR chips. ${ }^{52,53}$ A total of 52 As gene targets could be detected by both conventional qPCR and AsChip, whereas an additional seven As genes could only be detected by AsChip suggesting a higher sensitivity of AsChip. Other possible explanations for the observed slight differences between results obtained with the two qPCR platforms include automated versus manual qPCR reagent handling, laboratory contaminations, and inaccuracies of DNA quality quantified by UV absorbance.

Application of AsChip. AsChip analysis was carried out on DNA extracted from three Danish top soils collected from a site contaminated with different levels of chromium, copper, and arsenic. The three soils were labeled "low", "medium", or "high", depending on the arsenic contamination level (33, 203, or $2839 \mu \mathrm{g} \mathrm{As} \mathrm{g}^{-1}$, respectively). The absolute abundances of As genes (copies per gram of soil) ranged from $8.28 \times 10^{9}$ to $1.34 \times 10^{11}$ (average of $7.30 \times 10^{10}$; Table S4), but total normalized abundances varied much less and were $0.43,0.51$, and 0.32 in low, medium, and high contaminated soils. Hence, our data indicate that the overall As gene abundance did not vary much with soil As contamination level.

The normalized abundance of individual As genes are shown in Figure 6. Out of 19 different As genes, 17 could be detected in the three soils demonstrating high potential for microbial As transformations. Remarkably, the arxA gene encoding the arsenite oxidase in chemoautotrophic arsenite-oxidizing bacteria ( $\mathrm{CAO}$ ) was not detected in any of the three contaminated soils suggesting that these specialized bacteria generating energy from the oxidation of arsenite with molecular oxygen or nitrate as terminal electron acceptor were not active in the studied soils. This finding is consistent with arsenate being the dominant inorganic As species and the

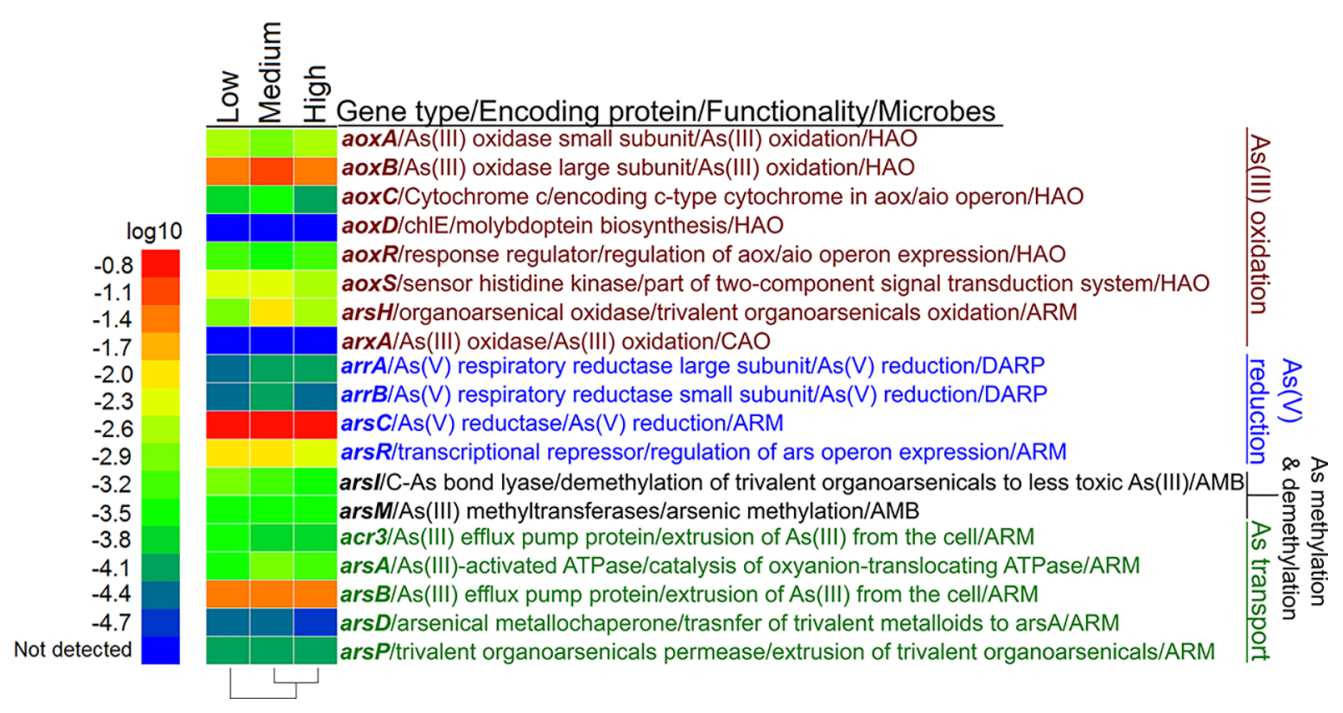

Figure 6. $\log _{10}$ transformed normalized As gene abundance (copy number per $16 \mathrm{~S}$ rRNA) of 19 genes of relevance for microbe-mediated biogeochemical cycling of As in three top soils. Soils were collected from a chromium-copper-arsenic-contaminated site and named "Low" ( $33 \mu \mathrm{g}$ As $\left.\mathrm{g}^{-1}\right)$, "Medium" (203 $\left.\mu \mathrm{g} \mathrm{As} \mathrm{g}^{-1}\right)$, or "High" $\left(2839 \mu \mathrm{g} \mathrm{As} \mathrm{g}^{-1}\right) \mathrm{y}$. Samples were clustered based on Pearson distance using hierarchical algorithms (average linkage cluster). Abbreviations used: HAO, heterotrophic arsenite oxidizers; ARM, arsenic resistant microorganisms; CAO, chemoautotrophic arsenite oxidizers; DARP, dissimilatory arsenate-reducing prokaryotes. 
anticipated absence of an As redox stratification in the studied upland soils. $^{54-56}$

Two of the most abundant As genes were arsB (0.0490.069 copies per $16 \mathrm{~S}$ rRNA gene) and $\operatorname{ars} C(0.18-0.30$ copies per 16S rRNA gene). Collectively, these genes encode arsenate resistance by the arsenate reduction-arsenite efflux pathway. ${ }^{18}$ Hence, our AsChip data indicates that the ars $B C$ encoded resistance mechanism is very common in bacteria irrespective of the As contamination level of their natural habitats. This is consistent with the frequent occurrence of $\operatorname{ars} B C$ in cultured bacteria (e.g., Escherichia coli) isolated from noncontaminated habitats. ${ }^{30}$ Interestingly, AsChip also consistently detected a series of As genes (arsH, arsI, and arsM) involved in recently discovered parallel pathways for organoarsenical biotransformation and detoxification. ${ }^{23}$ The ars $M$ gene encodes a As(III) S-adenosylmethionine methyltransferase that transforms inorganic arsenite into the even more toxic organoarsenical methyl arsenite (a human carcinogen) which can be rapidly oxidized to its less toxic pentavalent form, whereas arsI and ars $H$ encode different methyl arsenite detoxification mechanisms. ${ }^{23,57}$ Other arsenic-resistant genes (arsADRP, acr3) were also detected in our samples demonstrating the existence of several parallel As resistance pathways in the studied microbial communities.

AoxABCRS genes (also called aioABCRS) ${ }^{18}$ are involved in heterotrophic arsenite oxidation and were detected in all samples with the aoxB gene being the most abundant of the aox genes and the second most abundant As gene overall (0.04, 0.11, and 0.07 copies per 16S rRNA gene in low, medium, and high contaminated soil, respectively). The aoxB gene (large Mo-protein subunit of As(III) oxidase at $7.1 \times 10,{ }^{9}$ $2.8 \times 10^{10}$, and $1.7 \times 10^{9}$ copies $\mathrm{g}^{-1}$, correspondingly) was 10 , 45 and 26 folds more abundant than the aoxA gene (small FeS Rieske subunit of As(III) oxidase, $5.7 \times 10,{ }^{8} 6.3 \times 10^{8}$, and $6.7 \times 10^{7}$ copies $\mathrm{g}^{-1}$, correspondingly) in the soils named low, medium, and high, respectively (Table S4). ${ }^{58}$ This was not due to differences in PCR amplification efficiencies and could thus most likely be attributed to lower coverage of the primers used for $a \circ x A$ as compared to $a \circ x B$. This interpretation is consistent with $a \circ x B$ (also named aio $A$ ) being more frequently studied as compared to aoxA (also named aioB), and more target sequences were thus available in databases for aox $B$ primer design. Nevertheless, differences in the normalized abundance for the three studied soils followed the same order for both aox $A$ and aoxB suggesting that the current first-generation AsChip can still be used to monitor relative differences between samples. In contrast to the aox $A B$ gene pair, the genes $\operatorname{arr} A$ and $\operatorname{arr} B$ encoding the large and the small subunit of $\mathrm{As}(\mathrm{V})$ reductase in dissimilatory arsenate-reducing prokaryotes (DARPs) were found in near equal abundances for each soil, suggesting that AsChip primers used for detection of arrA and $\operatorname{arr} B$ displayed similar bacterial community coverage. Hence, $\operatorname{arr} A$ gene copy numbers were $6.2 \times 10,{ }^{6} 2.4 \times 10^{7}$, and $2.1 \times$ $10^{6}$ in soil named low, medium, and high, whereas corresponding numbers for $\operatorname{arr} B$ were $10.0 \times 10,{ }^{6} 2.9 \times 10^{7}$, and $1.2 \times 10^{6}$ copies $\mathrm{g}^{-1}$, respectively (Table S4).

To our knowledge, AsChip represents the first HT-qPCRbased chip for As genes, and our results indicate that it can be used as a robust and reliable tool for comprehensive quantitative profiling of As genes in environmental samples. Hence, AsChip provides specific, sensitive, and targeted quantification of As genes and may be used in various environments for better understanding of As microbe- mediated biotransformations and its biogeochemical cycling. The high sensitivity and PCR reaction minituarization allow AsChip analysis to be performed with only a small amount of template DNA. Furthermore, HT-qPCR-based chips have already been successfully developed and applied for profiling other genes in various environments. ${ }^{42,59-63}$ Consequently, HT-qPCR data analysis is already well developed and allows researchers to perform absolute quantification, ${ }^{42}$ relative quantification, $^{50,64}$ or comparative quantification ${ }^{61,65,66}$ of the targeted genes. Moreover, results obtained from AsChip may potentially be used to link detected As genes to their putative microbial hosts via the Primer-BLAST tool. ${ }^{43}$ The microarraybased GeoChip ${ }^{39}$ also includes probes targeting As genes and has been used in a previous study of As biotransformation processes. ${ }^{67}$ However, the GeoChip was designed for a wide range of functional genes and not specifically for As genes, and only a limited diversity of As genes were targeted (i.e., $\operatorname{ars} A B C M$ and $a \circ x B$ ). Compared with GeoChip, AsChip presented in this study thus displays better As gene coverage and, most likely, higher sensitivity for As gene quantification.

Although the current first-generation AsChip has great potential as a comprehensive molecular tool for studies of microbial As cycling, novel functional groups of Asbiotransforming prokaryotes and As genes not matching the current AsChip primers are likely to be discovered and characterized in the future. This implies that AsChip will have to be further refined and improved. The literature already contains reports of As genes that were not included in AsChip design. For instance, two novel arsenic resistance genes ars $O$ (for a putative flavin-binding monooxygenase) and ars $T$ (for a putative thioredoxin reductase) were reported in a previous study. ${ }^{68}$ Likewise, the As resistance genes arsN (encoding acetyltransferase), ${ }^{69}$ arsJ (encoding organoarsenical efflux permease), ${ }^{70}$ and $g s t B$ (encoding glutathione S-transferase B) $)^{71}$ were reported previously, but only limited coding sequence information is currently available for primer design. Despite these limitations, AsChip offers unprecedended potential for targeted, yet comprehensive, quantification of As genes in environmental samples. We propose that AsChip may be applied together with other "omics" methods and (geo)chemical analysis in future studies of As resistance, biotransformation, and biogeochemistry. Such polyphasic approaches may reconcile geochemical and genomics data for the development of systems models to predict the fate and impacts of As and the movement of microorganisms in the environment. $^{18,72}$

\section{ASSOCIATED CONTENT}

\section{S Supporting Information}

The Supporting Information is available free of charge on the ACS Publications website at DOI: 10.1021/acs.est.8b03798.

Standard curves obtained with all 70 newly designed AsChip primers (Figure S1); parameters of standard curves (Table S2); optimal cutoff point, LoD, and LoQ (Table S3); absolute abundances of the 16S rRNA gene and As genes involving different functional processes in three soils (Table S4). (PDF)

Detailed information on 81 AsChip primer sets and their targets (Table S1). (XLSX) 


\section{AUTHOR INFORMATION}

\section{Corresponding Authors}

*Yong-Guan Zhu. E-mail: ygzhu@iue.ac.cn, ygzhu@rcees.ac. cn. Phone: +86-592-6190997.

*Kristian Koefoed Brandt. E-mail: kkb@plen.ku.dk. Phone: $+45-35332612$.

\section{ORCID}

Jian-Qiang Su: 0000-0003-1875-249X

Yong-Guan Zhu: 0000-0003-3861-8482

Kristian Koefoed Brandt: 0000-0001-7886-9708

\section{Notes}

The authors declare no competing financial interest.

\section{ACKNOWLEDGMENTS}

We thank Bangxiao Zheng for advice on chip design. This work was supported financially by REMEDIATE (Improved decision-making in contaminated land site investigation and risk assessment) Marie-Curie Innovation Training Network from the European Union's Horizon 2020 Programme (Grant Agreement No. 643087).

\section{REFERENCES}

(1) Abernathy, C. O.; Thomas, D. J.; Calderon, R. L. Health effects and risk assessment of arsenic. J. Nutr. 2003, 133 (5), 1536S-1538S.

(2) Zhu, Y. G.; Yoshinaga, M.; Zhao, F. J.; Rosen, B. P. Earth abides arsenic biotransformations. Annu. Rev. Earth Planet. Sci. 2014, 42, 443-467.

(3) Oremland, R. S.; Stolz, J. F. The ecology of arsenic. Science 2003, 300 (5621), 939-944.

(4) Chen, W. Q.; Shi, Y. L.; Wu, S. L.; Zhu, Y. G. Anthropogenic arsenic cycles: a research framework and features. J. Cleaner Prod. 2016, 139, 328-336.

(5) Ferguson, J. F.; Gavis, J. A review of the arsenic cycle in natural waters. Water Res. 1972, 6 (11), 1259-1274.

(6) Smith, A. H.; Lingas, E. O.; Rahman, M. Contamination of drinking-water by arsenic in Bangladesh: a public health emergency. Bull. World Health Organ. 2000, 78 (9), 1093-1103.

(7) Brammer, H.; Ravenscroft, P. Arsenic in groundwater: a threat to sustainable agriculture in South and South-east Asia. Environ. Int. 2009, 35 (3), 647-54.

(8) Zhao, F. J.; McGrath, S. P.; Meharg, A. A. Arsenic as a food chain contaminant: mechanisms of plant uptake and metabolism and mitigation strategies. Annu. Rev. Plant Biol. 2010, 61, 535-59.

(9) Ng, J. C.; Wang, J.; Shraim, A. A global health problem caused by arsenic from natural sources. Chemosphere 2003, 52 (9), 1353-1359.

(10) Smith, A. H.; Hopenhayn-Rich, C.; Bates, M. N.; Goeden, H. M.; Hertz-Picciotto, I.; Duggan, H. M.; Wood, R.; Kosnett, M. J.; Smith, M. T. Cancer risks from arsenic in drinking water. Environ. Health Perspect. 1992, 97, 259.

(11) States, J. C.; Srivastava, S.; Chen, Y.; Barchowsky, A. Arsenic and cardiovascular disease. Toxicol. Sci. 2009, 107 (2), 312-23.

(12) Lai, M. S.; Hsueh, Y. M.; Chen, C. J.; Shyu, M. P.; Chen, S. Y.; Kuo, T. L.; Wu, M. M.; Tai, T. Y. Ingested inorganic arsenic and prevalence of diabetes mellitus. Am. J. Epidemiol. 1994, 139 (5), 484492.

(13) Tseng, C.; Blackfoot, H. Blackfoot disease and arsenic: a neverending story. J. Environ. Sci. Health. C. Environ. Carcinog. Ecotoxicol Rev. 2005, 23 (1), 55-74.

(14) Cullen, W. R.; Reimer, K. J. Arsenic speciation in the environment. Chem. Rev. 1989, 89 (4), 713-764.

(15) Akter, K. F.; Owens, G.; Davey, D. E.; Naidu, R. Arsenic Speciation and Toxicity in Biological Systems. Rev. Environ. Contam. Toxicol. 2005, 184, 97-149.

(16) Vega, L.; Styblo, M.; Patterson, R.; Cullen, W.; Wang, C.; Germolec, D. Differential effects of trivalent and pentavalent arsenicals on cell proliferation and cytokine secretion in normal human epidermal keratinocytes. Toxicol. Appl. Pharmacol. 2001, 172 (3), 225-232.

(17) Sforna, M. C.; Philippot, P.; Somogyi, A.; van Zuilen, M. A.; Medjoubi, K.; Schoepp-Cothenet, B.; Nitschke, W.; Visscher, P. T. Evidence for arsenic metabolism and cycling by microorganisms 2.7 billion years ago. Nat. Geosci. 2014, 7 (11), 811-815.

(18) Zhu, Y. G.; Xue, X. M.; Kappler, A.; Rosen, B. P.; Meharg, A. A. Linking genes to microbial biogeochemical cycling: lessons from arsenic. Environ. Sci. Technol. 2017, 51 (13), 7326-7339.

(19) Turpeinen, R.; Pantsar-Kallio, M.; Kairesalo, T. Role of microbes in controlling the speciation of arsenic and production of arsines in contaminated soils. Sci. Total Environ. 2002, 285 (1), 133145.

(20) Oremland, R. S.; Stolz, J. F. Arsenic, microbes and contaminated aquifers. Trends Microbiol. 2005, 13 (2), 45-9.

(21) Qin, J.; Rosen, B. P.; Zhang, Y.; Wang, G.; Franke, S.; Rensing, C. Arsenic detoxification and evolution of trimethylarsine gas by a microbial arsenite S-adenosylmethionine methyltransferase. Proc. Natl. Acad. Sci. U. S. A. 2006, 103 (7), 2075-80.

(22) Yan, Y.; Ye, J.; Xue, X. M.; Zhu, Y. G. Arsenic Demethylation by a C.As Lyase in Cyanobacterium Nostoc sp. PCC 7120. Environ. Sci. Technol. 2015, 49 (24), 14350-8.

(23) Yang, H. C.; Rosen, B. P. New mechanisms of bacterial arsenic resistance. Biomed. J. 2016, 39 (1), 5-13.

(24) Yoshinaga, M.; Cai, Y.; Rosen, B. P. Demethylation of methylarsonic acid by a microbial community. Environ. Microbiol. 2011, 13 (5), 1205-15.

(25) Xiao, K. Q.; Li, L. G.; Ma, L. P.; Zhang, S. Y.; Bao, P.; Zhang, T.; Zhu, Y. G. Metagenomic analysis revealed highly diverse microbial arsenic metabolism genes in paddy soils with low-arsenic contents. Environ. Pollut. 2016, 211, 1-8.

(26) Rascovan, N.; Maldonado, J.; Vazquez, M. P.; Eugenia Farias, M. Metagenomic study of red biofilms from Diamante Lake reveals ancient arsenic bioenergetics in haloarchaea. ISME J. 2016, 10 (2), 299-309.

(27) Cai, L.; Yu, K.; Yang, Y.; Chen, B. W.; Li, X. D.; Zhang, T. Metagenomic exploration reveals high levels of microbial arsenic metabolism genes in activated sludge and coastal sediments. Appl. Microbiol. Biotechnol. 2013, 97 (21), 9579-9588.

(28) Zhang, S. Y.; Zhao, F. J.; Sun, G. X.; Su, J. Q.; Yang, X. R.; Li, H.; Zhu, Y. G. Diversity and abundance of arsenic biotransformation genes in paddy soils from southern China. Environ. Sci. Technol. 2015, 49 (7), 4138-46.

(29) Giloteaux, L.; Holmes, D. E.; Williams, K. H.; Wrighton, K. C.; Wilkins, M. J.; Montgomery, A. P.; Smith, J. A.; Orellana, R.; Thompson, C. A.; Roper, T. J.; et al. Characterization and transcription of arsenic respiration and resistance genes during in situ uranium bioremediation. ISME J. 2013, 7 (2), 370.

(30) Zhang, S. Y.; Su, J. Q.; Sun, G. X.; Yang, Y.; Zhao, Y.; Ding, J.; Chen, Y. S.; Shen, Y.; Zhu, G.; Rensing, C.; Zhu, Y. G. Land scale biogeography of arsenic biotransformation genes in estuarine wetland. Environ. Microbiol. 2017, 19 (6), 2468-2482.

(31) Achour, A. R.; Bauda, P.; Billard, P. Diversity of arsenite transporter genes from arsenic-resistant soil bacteria. Res. Microbiol. 2007, 158 (2), 128-37.

(32) Giloteaux, L.; Holmes, D. E.; Williams, K. H.; Wrighton, K. C.; Wilkins, M. J.; Montgomery, A. P.; Smith, J. A.; Orellana, R.; Thompson, C. A.; Roper, T. J.; Long, P. E.; Lovley, D. R. Characterization and transcription of arsenic respiration and resistance genes during in situ uranium bioremediation. ISME J. 2013, 7 (2), 370-83.

(33) Jia, Y.; Huang, H.; Zhong, M.; Wang, F. H.; Zhang, L. M.; Zhu, Y. G. Microbial arsenic methylation in soil and rice rhizosphere. Environ. Sci. Technol. 2013, 47 (7), 3141-8.

(34) Reid, M. C.; Maillard, J.; Bagnoud, A.; Falquet, L.; Le Vo, P.; Bernier-Latmani, R. Arsenic Methylation Dynamics in a Rice Paddy Soil Anaerobic Enrichment Culture. Environ. Sci. Technol. 2017, 51 (18), 10546-10554. 
(35) Cai, L.; Liu, G.; Rensing, C.; Wang, G. Genes involved in arsenic transformation and resistance associated with different levels of arsenic-contaminated soils. BMC Microbiol. 2009, 9, 4.

(36) Saltikov, C. W.; Newman, D. K. Genetic identification of a respiratory arsenate reductase. Proc. Natl. Acad. Sci. U. S. A. 2003, 100 (19), 10983-8.

(37) Sun, Y.; Polishchuk, E. A.; Radoja, U.; Cullen, W. R. Identification and quantification of ars $\mathrm{C}$ genes in environmental samples by using real-time PCR. J. Microbiol. Methods 2004, 58 (3), 335-49.

(38) Whetzel, P. L.; Parkinson, H.; Causton, H. C.; Fan, L.; Fostel, J.; Fragoso, G.; Game, L.; Heiskanen, M.; Morrison, N.; Rocca-Serra, P.; et al. The MGED Ontology: a resource for semantics-based description of microarray experiments. Bioinformatics 2006, 22 (7), 866-873.

(39) He, Z.; Gentry, T. J.; Schadt, C. W.; Wu, L.; Liebich, J.; Chong, S. C.; Huang, Z.; Wu, W.; Gu, B.; Jardine, P.; Criddle, C.; Zhou, J. GeoChip: a comprehensive microarray for investigating biogeochemical, ecological and environmental processes. ISME J. 2007, 1 (1), 67-77.

(40) Dieffenbach, C.; Lowe, T.; Dveksler, G. General concepts for PCR primer design. Genome Res. 1993, 3 (3), S30-S37.

(41) Innis, M. A.; Gelfand, D. H.; Sninsky, J. J.; White, T. J. PCR Protocols: A Guide to Methods and Applications; Academic Press, 2012.

(42) Zhu, Y. G.; Zhao, Y.; Li, B.; Huang, C. L.; Zhang, S. Y.; Yu, S.; Chen, Y. S.; Zhang, T.; Gillings, M. R.; Su, J. Q. Continental-scale pollution of estuaries with antibiotic resistance genes. Nat. Microbiol. 2017, 2, 16270.

(43) Ye, J.; Coulouris, G.; Zaretskaya, I.; Cutcutache, I.; Rozen, S.; Madden, T. L. Primer-BLAST: A tool to design target-specific primers for polymerase chain reaction. BMC Bioinf. 2012, 13 (1), 134.

(44) Nielsen, S. S.; Kjeldsen, P.; Jakobsen, R. Full scale amendment of a contaminated wood impregnation site with iron water treatment residues. Front. Environ. Sci. Eng. 2016, 10 (4), 3.

(45) Su, J. Q.; An, X. L.; Li, B.; Chen, Q. L.; Gillings, M. R.; Chen, H.; Zhang, T.; Zhu, Y. G. Metagenomics of urban sewage identifies an extensively shared antibiotic resistome in China. Microbiome 2017, 5 (1), 84.

(46) Sanger, F.; Nicklen, S.; Coulson, A. R. DNA sequencing with chain-terminating inhibitors. Proc. Natl. Acad. Sci. U. S. A. 1977, 74 (12), 5463-5467.

(47) Korbie, D. J.; Mattick, J. S. Touchdown PCR for increased specificity and sensitivity in PCR amplification. Nat. Protoc. 2008, 3 (9), 1452-6.

(48) Tardif, S.; Cipullo, S.; Sø, H. U.; Wragg, J.; Holm, P. E.; Coulon, F.; Brandt, K. K.; Cave, M. Factors governing the solid phase distribution of $\mathrm{Cr}, \mathrm{Cu}$ and As in contaminated soil after 40 years of ageing. Sci. Total Environ. 2019, 652, 744-745.

(49) Pei, R.; Kim, S. C.; Carlson, K. H.; Pruden, A. Effect of river landscape on the sediment concentrations of antibiotics and corresponding antibiotic resistance genes (ARG). Water Res. 2006, 40 (12), 2427-35.

(50) Looft, T.; Johnson, T. A.; Allen, H. K.; Bayles, D. O.; Alt, D. P.; Stedtfeld, R. D.; Sul, W. J.; Stedtfeld, T. M.; Chai, B.; Cole, J. R.; Hashsham, S. A.; Tiedje, J. M.; Stanton, T. B. In-feed antibiotic effects on the swine intestinal microbiome. Proc. Natl. Acad. Sci. U. S. A. 2012, 109 (5), 1691.

(51) Deng, W.; Wang, Y.; Liu, Z.; Cheng, H.; Xue, Y. HemI: a toolkit for illustrating heatmaps. PLoS One 2014, 9 (11), No. e111988.

(52) Brenan, C.; Morrison, T. High throughput, nanoliter quantitative PCR. Drug Discovery Today: Technol. 2005, 2 (3), 247-53.

(53) Stedtfeld, R. D.; Baushke, S. W.; Tourlousse, D. M.; Miller, S. M.; Stedtfeld, T. M.; Gulari, E.; Tiedje, J. M.; Hashsham, S. A. Development and experimental validation of a predictive threshold cycle equation for quantification of virulence and marker genes by high-throughput nanoliter-volume PCR on the OpenArray platform. Appl. Environ. Microbiol. 2008, 74 (12), 3831-8.
(54) MacNair, M. R.; Cumbes, Q. J.; Meharg, A. A. The genetics of arsenate tolerance in Yorkshire fog, Holcus lanatus L. Heredity 1992, 69 (4), 325.

(55) Meharg, A. A.; Hartley-Whitaker, J. Arsenic uptake and metabolism in arsenic resistant and nonresistant plant species. New Phytol. 2002, 154 (1), 29-43.

(56) Frick, H.; Tardif, S.; Kandeler, E.; Holm, P. E.; Brandt, K. K. Assessment of biochar and zero-valent iron for in-situ remediation of chromated copper arsenate contaminated soil. Sci. Total Environ. 2018, 655, 414-22.

(57) Ye, J.; Rensing, C.; Rosen, B. P.; Zhu, Y. G. Arsenic biomethylation by photosynthetic organisms. Trends Plant Sci. 2012, 17 (3), 155-62.

(58) Muller, D.; Lievremont, D.; Simeonova, D. D.; Hubert, J. C.; Lett, M. C. Arsenite oxidase aox genes from a metal-resistant $\beta$ proteobacterium. J. Bacteriol. 2003, 185 (1), 135-141.

(59) Dahl, A.; Sultan, M.; Jung, A.; Schwartz, R.; Lange, M.; Steinwand, M.; Livak, K. J.; Lehrach, H.; Nyarsik, L. Quantitative PCR based expression analysis on a nanoliter scale using polymer nano-well chips. Biomed. Microdevices 2007, 9 (3), 307-14.

(60) Stedtfeld, R. D.; Williams, M. R.; Fakher, U.; Johnson, T. A.; Stedtfeld, T. M.; Wang, F.; Khalife, W. T.; Hughes, M.; Etchebarne, B. E.; Tiedje, J. M.; Hashsham, S. A. Antimicrobial resistance dashboard application for mapping environmental occurrence and resistant pathogens. FEMS Microbiol. Ecol. 2016, 92 (3), fiw020.

(61) Zhu, Y. G.; Johnson, T. A.; Su, J. Q.; Qiao, M.; Guo, G. X.; Stedtfeld, R. D.; Hashsham, S. A.; Tiedje, J. M. Diverse and abundant antibiotic resistance genes in Chinese swine farms. Proc. Natl. Acad. Sci. U. S. A. 2013, 110 (9), 3435-40.

(62) Su, J. Q.; Wei, B.; Ou-Yang, W. Y.; Huang, F. Y.; Zhao, Y.; Xu, H. J.; Zhu, Y. G. Antibiotic resistome and its association with bacterial communities during sewage sludge composting. Environ. Sci. Technol. 2015, 49 (12), 7356-63.

(63) Morrison, T.; Hurley, J.; Garcia, J.; Yoder, K.; Katz, A.; Roberts, D.; Cho, J.; Kanigan, T.; Ilyin, S. E.; Horowitz, D.; Dixon, J. M.; Brenan, C. J. Nanoliter high throughput quantitative PCR. Nucleic Acids Res. 2006, 34 (18), e123.

(64) Pfaffl, M. W. Quantification strategies in real-time PCR. In A-Z. of Quantitative PCR; Bustin, S. A., Eds.; International University Line: La Jolla, CA, USA, 2004; pp 87-112.

(65) Livak, K. J.; Schmittgen, T. D. Analysis of relative gene expression data using real-time quantitative PCR and the 2(-Delta Delta C(T)) Method. Methods 2001, 25 (4), 402-8.

(66) Schmittgen, T. D.; Livak, K. J. Analyzing real-time PCR data by the comparative CT method. Nat. Protoc. 2008, 3 (6), 1101-1108.

(67) Lomax, C.; Liu, W. J.; Wu, L.; Xue, K.; Xiong, J.; Zhou, J.; McGrath, S. P.; Meharg, A. A.; Miller, A. J.; Zhao, F. J. Methylated arsenic species in plants originate from soil microorganisms. New Phytol. 2012, 193 (3), 665-72.

(68) Wang, L.; Chen, S.; Xiao, X.; Huang, X.; You, D.; Zhou, X.; Deng, Z. arsRBOCT arsenic resistance system encoded by linear plasmid pHZ227 in Streptomyces sp. strain FR-008. Appl. Environ. Microbiol. 2006, 72 (5), 3738-42.

(69) Chauhan, N. S.; Ranjan, R.; Purohit, H. J.; Kalia, V. C.; Sharma, $\mathrm{R}$. Identification of genes conferring arsenic resistance to Escherichia coli from an effluent treatment plant sludge metagenomic library. FEMS Microbiol. Ecol. 2009, 67 (1), 130-9.

(70) Chen, J.; Yoshinaga, M.; Garbinski, L. D.; Rosen, B. P. Synergistic interaction of glyceraldehydes-3-phosphate dehydrogenase and ArsJ, a novel organoarsenical efflux permease, confers arsenate resistance. Mol. Microbiol. 2016, 100 (6), 945-53.

(71) Chrysostomou, C.; Quandt, E. M.; Marshall, N. M.; Stone, E.; Georgiou, G. An alternate pathway of arsenate resistance in E. coli mediated by the glutathione S-transferase GstB. ACS Chem. Biol. 2015, 10 (3), 875-82.

(72) Zhu, Y. G.; Gillings, M.; Simonet, P.; Stekel, D.; Banwart, S.; Penuelas, J. Human dissemination of genes and microorganisms in Earth's Critical Zone. Glob. Chang. Biol. 2018, 24 (4), 1488-1499. 
(73) Sardiwal, S.; Santini, J. M.; Osborne, T. H.; Djordjevic, S. Characterization of a two-component signal transduction system that controls arsenite oxidation in the chemolithoautotroph NT-26. FEMS Microbiol. Lett. 2010, 313 (1), 20-8.

(74) Heinrich-Salmeron, A.; Cordi, A.; Brochier-Armanet, C.; Halter, D.; Pagnout, C.; Abbaszadeh-fard, E.; Montaut, D.; Seby, F.; Bertin, P. N.; Bauda, P.; Arsene-Ploetze, F. Unsuspected diversity of arsenite-oxidizing bacteria as revealed by widespread distribution of the aoxB gene in prokaryotes. Appl. Environ. Microbiol. 2011, 77 (13), 4685-92.

(75) Zargar, K.; Conrad, A.; Bernick, D. L.; Lowe, T. M.; Stolc, V.; Hoeft, S.; Oremland, R. S.; Stolz, J.; Saltikov, C. W. ArxA, a new clade of arsenite oxidase within the DMSO reductase family of molybdenum oxidoreductases. Environ. Microbiol. 2012, 14 (7), 1635-45.

(76) Malasarn, D.; Saltikov, C. W.; Campbell, K. M.; Santini, J. M.; Hering, J. G.; Newman, D. K. arrA is a reliable marker for As(V) respiration. Science 2004, 306 (5695), 455.

(77) Rosen, B. P. Biochemistry of arsenic detoxification. FEBS Lett. 2002, 529 (1), 86-92.

(78) Lin, Y. F.; Walmsley, A. R.; Rosen, B. P. An arsenic metallochaperone for an arsenic detoxification pump. Proc. Natl. Acad. Sci. U. S. A. 2006, 103 (42), 15617-22.

(79) Tisa, L. S.; Rosen, B. P. Molecular characterization of an anion pump. The ArsB protein is the membrane anchor for the ArsA protein. J. Biol. Chem. 1990, 265 (1), 190-194.

(80) Chen, J.; Madegowda, M.; Bhattacharjee, H.; Rosen, B. P. ArsP: a methylarsenite efflux permease. Mol. Microbiol. 2015, 98 (4), 62535 .

(81) Bobrowicz, P.; Wysocki, R.; Owsianik, G.; Goffeau, A.; Ułaszewski, S. Isolation of three contiguous genes, ACR1, ACR2 and ACR3, involved in resistance to arsenic compounds in the yeast Saccharomyces cerevisiae. Yeast 1997, 13 (9), 819-828.

(82) Ben Fekih, I.; Zhang, C.; Li, Y. P.; Zhao, Y.; Alwathnani, H. A.; Saquib, Q.; Rensing, C.; Cervantes, C. Distribution of arsenic resistance genes in prokaryotes. Front. Microbiol. 2018, 9, 2473. 